Jurnal Ilmiah Mahasiswa Fakultas Hukum (JIM FH)

E-ISSN 2798-8457

Volume IV Nomor 2 (April 2021)

Fakultas Hukum Universitas Malikussaleh universitas MALIKUSSALEH

The Blessing University

\title{
PERLINDUNGAN HUKUM TERHADAP KERAJINAN KERAWANG GAYO LUES \\ (Studi Penelitian di Kecamatan Blangkejeren Kabupaten Gayo Lues)
}

\author{
${ }^{1}$ Roiyani, ${ }^{2}$ Nasrianti, ${ }^{3}$ Arif Rahman \\ ${ }^{1}$ Mahasiswa Dosen Fakultas Hukum Universitas Malikussaleh \\ ${ }^{2}$ Dosen Fakultas Hukum Universitas Malikussaleh
}

\begin{abstract}
Abstrak
Salah satu kebanggan dari masyarakat gayo lues adalah kerawang gayo, tetapi banyak masyarakat luar yang mengira kerawang gayo ini hanya dimiliki oleh satu daerah yaitu Aceh Tengah padahal setiap daerah ini memiliki motif yang berbeda dari masing-masing kerawang. Selain itu, kerawang gayo juga terdapat di daerah lain seperti lukup (Aceh Timur). Dikatuktan akan diambil oleh pihak lain maka pemerintah berinisiatif mengajukan hak cipta nya. Permasalahan yang diangkat ialah bagaimana perlindungan hukum terhadap kerajinan kerawang gayo lues, serta bagaimanakah hambatan dalam perlindungan hukum terhadap kerajinan kerawang gayo lues serta apakah upaya mengatasi hambatan dari perlindungan terhadap kerajinan kerawang gayo lues. Metode dalam penelitian ini menggunakan jenis kualitatif, yaitu menggunakan pendekatan yuridis empiris dan bersifat deskriptif. Kerajinan kerawang gayo lues telah mendapatkan perlindungan hukum yaitu mendapat hak cipta pada awal 2020. Hambatan yang didapat ialah kurangnya sosialisasi dari pemerintah tentang pentingnya mendaftarkan kerawang gayo lues serta kurangnya pemahaman dari masyarakat gayo lues tentang perlindungan hukum dan upaya pemerintah adalah mendaftarkan kerawang gayo lues kepada HKI dan melakukan seminar sosialisasi kepada masyarakat yang membuka usaha di bidang kearwang gayo lues tersebut atau yang menggunakan motif kerswang gayo lues.
\end{abstract}

Kata kunci : perlindungan hukum, kerawang gayo lues. 


\section{PENDAHULUAN}

Kerawang Gayo Lues tersebut dapat didaftarkan hasilnya agar memperoleh sertifikat Hak atas Kekayaan Intelektual (HKI) dari Direktorat Jenderal Hak Cipta Kementerian Hukum dan HAM, tetapi harus melalui prosedur yang benar dan menurut ketentuan yang berlaku dan mendapatkan hak-hak dan kewajiban-kewajiban dari pencipta hasil karya tersebut akan senantiasa terjamin hasil karya nya dalam hak cipta yang terdaftar di Hak Kekayaan Intelektual (HKI). Perlindungan hak cipta bertujuan untuk melindungi kekhasan tersebut dari pemalsuan atau pemanfaatan yang tidak seharusnya sekaligus memberi kesempatan dan perlindungan kepada masyarakat wilayah penghasil produk khas tersebut. ${ }^{1}$

Menurut pendapat tokoh budaya dan adat jumlah motif kerawang Gayo Lues pada tahun 2018, berjumlah 11 motif yang terdiri dari mata itik, pucuk rebung, sesirung, leladu, mun berangkat, tulen iken, puter tali, bunge kipes, gegaping, panah dan motip selalu. ${ }^{2}$ Dalam kehidupan sehari-hari masyarakat mengenal atau menyebutkan nama-nama suatu barang yang diikuti dengan nama tempat atau daerah asal barang tersebut. Meskipun kerajinan kerawang Gayo Lues banyak dipakai oleh masyarakat tetapi masih banyak sekali yang belum mengetahui asal dari kerajinan kerawang Gayo Lues tersebut, begitu juga dengan keterangan warna dan motifnya. Bahkan ada masyarakat yang berpikir kerawang Gayo Lues ini berasal dari Aceh Tengah/Takengon. Pada kenyataannya kedua kerawang ini sangat berbeda, baik itu dari segi warna, motif dan maknanya. Permohonan untuk diajukan pendaftaran oleh lembaga yang mewakili masyarakat di kawasan tersebut dan pemerintah daerah provinsi atau kabupaten/kota tempat asal suatu barang atau produk berupa sumber daya alam, barang kerajinan tangan atau hasil industri. ${ }^{3}$

Pada Kecamatan Blangkejeren ada sekitar 20 orang, khususnya dI Kecamatan Blangkejeren yang membuka usaha di bidang kerajinan kerawang Gayo Lues tetapi tidak meminta izin terlebih dahulu. Motif kerawang Gayo Lues banyak kesamaan dengan motif kerawang daerah lain jika dilihat sekilas, sekarang ada tiga daerah yang memakai nama kerawang gayo namun setiap daerah memiliki motif yang berbeda. Dengan adanya kesamaan nama sehingga perlu dilakukan pendaftaran untuk kerawang Gayo Lues ini agar motifnya terlindungi. Seperti anyaman tikar gayo yang ditengahnya terdapat tulisan dan bunga, saat ini sudah di caplokan oleh orang luar menggunakan bahan bakuplastik dengan sistem sablon. Padahal anyaman tikar gayo itu merupakan ikon Gayo Lues yang sudah turun-temurun dibuat oleh anak gadis Gayo Lues.Berdasarkan latar belakang diatas menjadi dasar bagi penulis untuk melakukan penelitian yang berjudul "Perlindungan Hukum Terhadap Kerajinan Kerawang Gayo Lues (Studi Penelitian di Kecamatan Blangkejeren Kabupaten Gayo Lues)". Dari latar belakang masalah di atas, maka dapat dirumuskan permasalahan sebagai berikut : Bagaimanakah perlindunngan hukum terhadap kerajinan kerawang Gayo Lues?. Bagaimanakah hambatan dalam perlindungan terhadap kerajinan kerawang Gayo Lues ?.Apakah upaya mengatasi hambatan dari perlindungan hukum terhadap kerajinan kerawang Gayo Lues?.

${ }^{1}$ Winda Risna Yustiningrum, Perlindungan Hukum Indikasi Geografis Sebagai Bagian Dari Hak Kekayaan Intelektual, Fakultas Magister Ilmu Hukum, Jurnal Hukum, Universitas Mataram, Dari Google scholar,dikutip dari jurnal hukum, diakses pada tanggal 25 november 2019.

2 Isma Tantawi dan Buniyamin, Pilar-Pilar Kebudayaan Gayo Lues, USU Prees, Medan, 2011, hlm. 72.

3 Candra Irwana, Pendaftaran Indikasi Geografis Sebagai Instrumen Perlindungan Hukum Dan Peningkatan Daya Saing Produk Di Daerah Indonesia, Jurnal Proceeding Sendi-U, Dari Google Scholar, Tanggal 25 Juni 2020. 


\section{METODE PENELITIAN}

Jenis penelitian ini termasuk dalam jenis kualitatif yang akan menghasilkan data deskriptif mengenai permasalahan terkait. Penelitian ini menggunakan pendekatan yuridis empiris yaitu suatu penelitian yang menekankan pada peraturan hukum yang berlaku dihubungkan dengan implementasinya dalam praktek. Penelitian ini bersifat deskriptif yaitu bertujuan menggambarkan secara tepat keadaan yang terjadi di lapangan. Dalam penelitian ini yang bersumber pada data primer dan data sekunder. Teknik pengumpulan data yang dilakukan dalam penulisan skripsi ini adalah penelitian lapangan (Field Research) dan penelitian kepustakaan (Library Research). Adapun alat yang digunakan dalam pengumpulan data yang digunakan dalam penelitian ini adalah hasil penelitian lapangan dan pedoman kepustakaan. Analisis data pada kegiatan yang dimulai dari kegiatan pengumpulan data. Adapun data yang diperoleh baik dari penelitian lapangan maupun studi dokumen adalah berdasarkan data primer yang diperoleh dari lapangan dan data sekunder yang ada kemudian dianalisis dengan menggunakan metode deskriptif kualitatif, yakni mendeskripsikan data yang diperoleh baik berupa kata-kata lisan atau tertulis dari pihak yang diwawancara.

Adapun responden dan informan dalam penelitian ini adalah :

1. 1 (satu) orang anggota dari Pembinaan Dekranas Kerawang Gayo Lues di Kecamatan Blangkejeren Kabupaten Gayo Lues.

2. 2 (dua) orang pengrajin kerajinan kerawang Gayo Lues di Kecamatan Blangkejeren Kabupaten Gayo Lues.

3. 2 (Dua) Orang Masyarakat Di Kecamatan Blangkejeren Kabupaten Gayo Lues.

a) Ketua Majelis Adat Aceh (MAA) Kabupaten Gayo Lues.

b) Kepala Dinas Perindustrian Kabupaten Gayo Lues.

c) Kepala Dinas Pariwisata Dan Kebudayaan Kabupaten Gayo Lues.

\section{HASIL PENELITIAN ATAU PEMBAHASAN}

\section{A. Perlindungan Hukum Terhadap Kerajinan Kerawang Gayo Lues}

Perlindungan hukum terhadap kerawang Gayo Lues harus didaftarkan karena itu menjadi salah satu pengenal atau identitas suatu suku yang bisa dikenal oleh suku atau budaya lain, dalam artian setiap orang melihat kerawang Gayo Lues ini, orang langsung paham bahwa itu adat budaya dari Gayo Lues, kalau kerawang Gayo Lues tidak mendapat perlindungan hukum atau tidak didaftarkan maka hasil budaya tersebut itu akan hilang dan tidak dikenal luas serta dianggap hal yang gak mesti dijaga, jika sudah didaftarkan otomatis semua orang pasti akan terus melestarikan suatu budaya, apalagi dari motif kerawang itu sangat bagus. ${ }^{4}$ Dalam praktek perlindungan hukum yang terjadi di Gayo Lues terhadap kerrawang Gayo Lues banyak pihak pengusaha yang tidak meminta izin walaupun demikian pemerintah tetap memperboleh untuk mereka membuka usaha namun karena seiring dengan berjalan waktu dan masyarakat gayo tidak semua berada dalam Kabupaten Gayo Lues, maka pihak pemerintah mengajukan pendaftaran kerawang Gayo Lues pada akhir desember tahun 2019. Kerajinan kerawang Gayo Lues walaupun berasal

${ }^{4}$ Siska Simesti Nazara, Masyarakat di kecamatan blangkejeren, Narasumber, Wawancara, Tanggal 13 Januari 2012. 
dari Gayo Lues tetapi pertama kali dibuat di Lukup atau Aceh Timur yang disebut dengan baju kerawang lukup.dengan adanya asal mula tersebut maka pihak wewenang dari Gayo Lues mengajukan hak paten untuk kerawang Gayo Lues. ${ }^{5}$

Pngrajin menyatakan bahwa mayoritas pengrajin kerawang Gayo Lues ini kurang mengetahui apa yang dimaksud dengan HKI dan hak cipta. Kurangnya pengetahuan pengrajin kerawang Gayo Lues yang pada umumnya hanya mencapai sekolah menengah pertama selain itu peran pemerintah daerah dalam melakukan sosialisasi atau penyuluhan terkait perlindungan hukum yang dapat dilekatkan pada produk kerajinan dirasa kurang. Kurangnya pengetahuan para pengrajin ini juga menyebabkan produk kerajinan atau motif kerawang Gayo Lues ini dapat di klaim oleh pengrajin kerawang di daerah lain. ${ }^{6}$ Dalam rangka memperoleh perlindungan hukum, terlebih lagi dalam memperoleh hak cipta terhadap suatu karya, pencipta maupun pemegang hak cipta harus memiliki inisiatif untuk mendaftarkan ciptaannya. Karena nantinya surat pendaftaran cipta tersebut dapat dijadikan alat bukti awal di pengadilan apabila timbul sengketa di kemudian hari terhadap ciptaan tersebut. ${ }^{7}$

Dengan adanya tempat pembinaan dari Dekranas, pengrajin bordir kerawang Gayo Lues khususnya di Kampung Sere Kecamatan Blangkejeren Kabupaten Gayo Lues dapat lebih mengembangkan lapangan kerja yang mampu mengelola usaha dengan lebih terarah apabila sudah didaftarkan. Kemudian apabila ada pengrajin yang ingin membuka usaha kerajinan kerawang Gayo Lues maka dapat bergabung dalam pembinaan tersebut. Perlunya perlindungan hukum ini untuk menghalangi niat orang yang ingin membuka usaha di daerah lain. ${ }^{8}$ Penulis menganalisis bahwa perlindungan hukum terhadap kerajinan kerawang Gayo Lues sudah mendapatkan hak cipta, tetapi sebahagian masyarakat tidak mematuhi aturan yaitu masyarakat yang membuka usaha dibidang tersebut tidak semuanya meminta izin kepada pemerintah sehingga apabila motif kerawang gayo lues ini di pakai pada baju yang di produksi oleh masyarakat dari daerah lain tidak memberikan pemohonan izin untuk membuka usaha.

\section{B. Hambatan Dalam Perlindungan Terhadap Kerajinan Kerawang Gayo Lues}

Hambatan yang menjadi penghambat untuk mendapatkan perlindungan terhadap kerajinan kerawang Gayo Lues adalah sebagai berikut : ${ }^{9}$

1. Kesepakatan dari masyarakat yang berbeda tentang motif karena masyarakat Gayo Lues ini terbagi dari beberapa kecamatan bahkan masyarakat Gayo Lues ini juga terdapat di Lukup atau Aceh Timur.

2. Tidak ada pihak khusus yang menangani permasalahan perlindungan hukum untuk kerajinan kerawang Gayo Lues. Ini disebabkan karena sedikitnya kesadaran dari pihak yang berwenang karena menganggap hal lain menjadi lebih penting dari pada perlindungan untuk kerawang Gayo Lues. jika ada kesadaran yang dimaksud hanya sebatas dikalangan tertentu yang menaruh perhatian pada masalah pemanfaatan hasil karya seni dari kerawang Gayo Lues tersebut.

\footnotetext{
${ }^{5}$ Kasim Junaidi, Ketua MAA Gayo Lues, Narasumber, Wawancara, Tanggal 04 November 2020.

${ }^{6}$ Sinati, Pengrajin Kerajinan Kerrawang Gayo Lues,Narasumber, Wawancara, Tanggal 05 November

${ }^{7}$ Rina Sulastri, Kepala Bidang Industri Gayo Lues, Narasumber, Wawancara, Tanggal 04 November 2020

${ }^{8}$ Asmaini, Guru Pengrajin di Dekranas Kerawang Gayo Lues Kecamatam Blangkejeren Kabupaten Gayo Lues, Narasumber, Wawancara, Tanggal 15 Januari 2020.

${ }^{9}$ Rina Sulastri, Kepala Bidang Industri Gayo Lues, Narasumber, Wawancara, Tanggal 04 November 2020.
} 
3. Kekhawatiran para pengrajin terhadap biaya-biaya yang akan dikeluarkan apabila melakukan pendaftaran HKI.

Menurut pendapat John Hendra, yang menjadi hambatannya adalah sebagai berikut : ${ }^{10}$

1. Ketidaktahuan pengrajin mengenai HKI, sosialisasi yang dilakukan mengenai HKI hanya untuk orangorang tertentu saja tidak secara keseluruhan

2. Kurangnya pengetahuan dan pemahaman masyarakat dalam hal pentingnya melakukan pendaftaran serta manfaat yang diperoleh dan prosedur untuk mendapatkan perlindungan tersebut. Masyarakat hanya bersifat menunggu dan cenderung pasif, sejauh ini masyarakat hanya menunggu upaya dari pemerintah untuk melakukan sosialisasi dalam rangka memberikan perlindungan hukum terhadap motif kerawang Gayo Lues.

3. Pemahaman pengrajin yang salah yakni menurutnya yang berhak mendaftarkan kerajinan kerawang ini adalah urusan dewan kerajinan nasional. Sebenarnya perajin sendiri, maupun kelompok konsumen dapat mengajukan permohonan pendaftaran indikasi geografis.

Kurangnya pemahaman mengenai HKI inilah salah satu penghambat dalam mendapatkan perlindungan. Padahal hal utama yang harus dilakukan untuk mendapat perlindungan adalah mendaftarkan kerajinan kerawang Gayo Lues tersebut ke Direktorat Jenderal HKI.Selanjutnya mengumpulkan pengrajin untuk diinformasikan bahwa kerawang Gayo Lues sudah mendapatkan hak paten. ${ }^{11}$ Sejauh ini hambatannya karena pembinaan yang dilakukan oleh pihak-pihak wewenang hanya sebatas promosi dan pemasaran. Seperti yang dilakukan pada tahun kemarin yakni promosi melalui pameran-pameran yang ada di daerah Gayo Lues seperti pameran busana kerajinan kerawang Gayo Lues. Kalau pembinaan secara keseluruhan terhadap pengrajin tidak dapat dilakukan secara berkala, mungkin dikarenakan waktu dan kapasitas yang kurang. Selain itu, walaupun diadakan acara sosialisasi atau seminar, tidak semua pengrajin mengikuti seminar tersebut. ${ }^{12}$

Hambatan dalam perlindungan hukum terhadap kerawang Gayo Lues yaitu dari satu sisi kurangnya pemahaman terhadap perlunya kerawang tersebut diberikan hak cipta, yang mereka tau bahwa kerawang Gayo Lues adalah kain adatnya dan kelalaian atau sikap kurang peduli dari pihak yang berpendidikan, padahal mereka paham bahwa itu perlu tapi memilih diam sedangkan dari segi lain mungkin ada yang berpikir dari dulu ketika tari saman diakui ingin memperjuangkan hal tersebut tapi mungkin terkendala karna ketidakpahaman harus dibawa kemana atau bisa jadi karena pemerintah yang dulu kurang peduli terhadap pendaftaran kerawang Gayo Lues. ${ }^{13}$

${ }^{10}$ Jhon Hendra, Kasi Adat Dan Budaya Di Dinas Pariwisata Gayo Lues, Wawancara, Tanggal 27 November 2020.

${ }^{11}$ Asmaini, Guru Pengrajin di Dekranas Kerawang Gayo Lues Kecamatam Blangkejeren Kabupaten Gayo Lues, Narasumber, Wawancara, Tanggal 15 Januari 2020

${ }^{12}$ Ervina Risky Ananda, Masyarakat Kecamatan Blangkejeren Kampung Durin Kabupaten Gayo Lues, Wawancara, Tanggal 1 November 2020.

${ }^{13}$ Siska Simesti Nazara, Masyarakat di kecamatan blangkejeren, Narasumber, Wawancara, Tanggal 13 Januari 2012. 
Dalam usaha kerawang Gayo Lues, faktor ekonomi juga merupakan yang terpenting dalam mendapatkan perlindungan, jika kurangnya perlindungan maka dalam pengiriman barang tidak menjamin keselamatan barang yang dikirim sehingga baik pemilik maupun pengrajin kerawang Gayo Lues harus memutar otak agar bisnis kerajinan kerawang Gayo Lues ini terus dapat berjalan dan berkembang. Kerawang Gayo Lues juga sudah mulai di ekspor ke luar daerah seperti Sumatera Utara, Aceh Selatan dan Aceh Besar. Faktor ekonomi juga membuat kurang aktifnya wadah masyarakat untuk berperan memajukan produk kerajinan kerawang Gayo Lues seperti melakukan pendaftaran guna memperoleh perlindungan hukum. ${ }^{14}$

Pengaruh dari pihak luar yang dapat mempengaruhi warga masyarakat Gayo Lues untuk melanggar HKI antara lain, pelanggaran HKI dilakukan untuk mengambil jalan pintas guna mendapatkan keuntungan yang sebesar-besarnya dari pelanggaran tersebut. Kemudian masyarakat yang sedikit pemahaman tentang hukum menganggap bahwa sanksi hukum yang dijatuhkan oleh pengadilan tidaklah berat. Ada sebahagian masyarakat yang bangga apabila karya cipta nya ditiru oleh orang lain karena mengira bahwa kerawang Gayo Lues ini tidak bisa diambil oleh pihak lain, tetapi karena adanya HKI maka hal ini sudah mulai hilang. Kemudian masyarakat tidak yang membeli kerawang Gayo Lues ini tidak memperhatikan apakah kerawang gayo yang dibeli tersebut berasal dari masyarakat Gayo Lues atau tidak, kerana hal ini lah pemerintah daerah mendaftarkan kerawang gayo disebabkan semakin banyak pihak luar yang mulai tertarik dengan kerawang Gayo Lues ini. ${ }^{15}$

Faktor penyebab terjadinya hambatan dalam perlindungan hukum terhadap kerajinan kerawang Gayo Lues adalah pengetahuan dan pemahaman terhadap hak kekayaan intelektual yang belum sepenuhnya dimengerti oleh masyarakat Gayo Lues yang memiliki usaha di bidang kerajinan kerawang Gayo Lues. Kemudian faktor ekonomi menjadi salah satu penghambat dalam memberikan sosialisasi terkait perlindungan hukum. Namun hal tersebut tidak dapat dicegah karena sebagian masyarakat yang masih kurang peduli terhadap perlindungan hukum untuk kerawang Gayo Lues. Selanjutnya ada beberapa pihak yang merasa bahwa tidak terlalu penting untuk mengurus perlindungan hukum terhadap kerawang Gayo Lues kerana sudah mendapatkan pengakuan oleh UNESCO untuk tari saman yang sekarang sudah dikenal di internasional.

\section{Upaya Mengatasi Hambatan Dari Perlindungan Hukum Terhadap Kerajinan Kerawang Gayo Lues.}

Adapun upaya yang dilakukan untuk mengatasi hambatan dari perlindungan hukum terhadap kerajinan kerawang Gayo Lues adalah sebagai berikut $:^{16}$

a. Melakukan seminar untuk memperkenalkan motif dan makna dari kerawang Gayo Lues karena ada beberapa daerah yang memiliki nama yang sama dengan kerawang Gayo Lues ini salah satu nya

\footnotetext{
${ }^{14}$ Sinati, Pengrajin Kerajinan Kerrawang Gayo Lues, Narasumber, Wawancara, Tanggal 05 November 2020

${ }^{15}$ Kasim Junaidi, Ketua MAA Gayo Lues, Narasumber, Wawancara, Tanggal 04 November 2020.

16 Jhon Hendra, Kasi Adat Dan Budaya Di Dinas Pariwisata Gayo Lues, Narasumber, Wawancara, Tanggal 27 November 2020.
} 
daerah lukup yang memiliki kerawang Gayo Lues. Karena takut diambil oleh orang lain maka pihakpihak yang berwenang melakukan pengajuan hak paten pada akhir bulan Desember Tahun 2019.

b. Masyarakat yang ingin memproduksi atau membuka usaha di bidang kerajinan kerawang Gayo Lues harus meminta izin kepada pihak yang berwenang, seperti Majelis Adat Aceh, Dinas Industri dan Dinas Pariwisata. Dalam Pasal 10 UU Merek dan Indikasi Geografis, menjelaskan bahwaPemakai indikasi geografis adalah pihak yang mendapat izin dari pemegang hak atas indikasi geografis yang terdaftar untuk mengolah dan/atau memasarkan barang dan/atau produk indikasi geografis.

c. Menjelaskan secara detail tentang perlindungan hukum yang diperoleh oleh kerawang Gayo Lues dan apa saja yang menjadi sanksi apabila ada pihak yang melanggar.

Dalam melindungi kerajinan kerawang Gayo Lues atau menjadi dapat dikenal oleh pihak luar, mereka melakukan pendokumentasian hasil karya kerajinan kerawang Gayo Lues kemudian diunggah ke media sosial agar pihak konsumen dari luar Gayo Lues dapat memesan. ${ }^{17}$ Upaya yang dilakukan adalah mengumpulkan semua jenis motif yang dimiliki oleh Gayo Lues untuk didaftarkan kerajinan kerawang Gayo Lues kepada HKI agar mendapatkan sertifikat hak cipta atau perlindungan hukum untuk kerawang Gayo Lues. Sebagaimana sertifikat ini mempunyai kekuatan pembuktian bahwa motif-motif yang terdiri dari 15 jenis motif yaitu mata itik, pucuk rebung, bunge panah, sesirung, bunge lapan, bunge tabor, sede rino, rempelis, gegaping, bunge kipes, tulen iken, puter tali, mun berangkat, lelado, dan tumpuk manis sudah dimiliki oleh Gayo Lues dan tidak dapat diambil oleh pihak lain. ${ }^{18}$

Dalam upaya yang dilakukan untuk mengatsi hambatan adalah pemerintah harus lebih mempelajari dan meneliti kerawang Gayo Lues itu lebih mendalam lagi agar dapat membuktikan bahwa kerawang Gayo Lues murni hak milik dari daerah Gayo Lues. ${ }^{19}$ Bahwa upaya yang dilakukan untuk mengatasi hambatan sudah mulai dilakukan setahun sebelum diperoleh hak cipta sebagai hasil salah satu dari ekspresi budaya tradisonal pada awal tahun 2020, hanya saja kendalanya dalam memberi sosialisasi kepada masyarakat karena masyarakat Gayo Lues ini juga terdapat didaerah lain seperti Aceh Tengah, Kota Cane dan Lukup atau Aceh Timur sehingga masyarakat dari daerah tersebut tidak mengatahui bahwa jika ingin membuka usaha menggunakan motif-motif kerawang Gayo Lues harus melampirkan surat permohonan izin usaha. ${ }^{20}$

Upaya yang dilakukan oleh pemerintah adalah memperkenalkan kerawang Gayo Lues melalui acara akad nikah, preweding dan pentas budaya seperti yang dipakai pada tari saman dan tari bines dari Gayo Lues. Kemudian setiap acara adat yang dilakukan di Gayo Lues selalu memakai kerawang Gayo Lues baik dari segi asesoris, pakaian dan kain atau upuh. ${ }^{21}$ Salah satu upayanya ialah membuat Dekranasda atau binaan kerawang Gayo Lues dengan tujuan menanamkan kesadaran masyarakat akan pentingnya kerajinan, memperhatikan dan memperjuangkan kepentingan pengusaha kecil dengan

${ }^{17}$ Sinati, Pengrajin, Narasumber, Wawancara, Tanggal05 November 2020.

${ }^{18}$ Rina Sulastri, Kepala BidangIndustri Gayo Lues. Narasumber, Wawancara, Tanggal 04 November 2020.

${ }^{19}$ Siska Simesti Nazara, Masyarakat di kecamatan blangkejeren, Narasumber, Wawancara, Tanggal 13 Januari 2012.

${ }^{20}$ Kasim Junaidi, Ketua Majelis Adat Aceh Gayo Lues, Narasumber, Wawancara,Tanggal 04 November 2020.

${ }^{21}$ Siti Suarni, Pengrajin, Narasumber, Wawancara, Tanggal 13 Januari 2021. 
semangat kewirausahaan, melakukan pembinaan dan bimbingan kepada pengrajin serta melestarikan budaya dan mengembangkan identitas budaya. ${ }^{22}$ Realitanya masih ada upaya yang belum optimal dilakukan oleh pemerintah dan pihak-pihak yang berwewenang mengurus pendaftaran, setelah diperoleh hak paten pemrintah harus lebih peduli lagi terhadap perlindungan hukum khususnya dibidang merek, indikasi geografis dan hak cipta agar dapat memperoleh pengakuan dari HKI karena masih banyak hasil karya yang berasal dari Gayo Lues selain tari saman dan kerawang Gayo Lues.

\section{Kesimpulan Dan Saran}

\section{A. Kesimpulan}

1. Kerajinan kerawang Gayo Lues telah mendapatkan perlindungan hukum yaitu mendapatkan hak cipta sebagai ekspresi budaya tradisonal berdasarkan Undang-Undang Nomor 28 Tahun 2014 tentang Hak Cipta sesuia dengan pasal 38, hak cipta ini di dapat pada bulan Januari tahun 2020 setelah didaftarkan pada akhir tahun 2019, kemudian dengan mengingat bahwah hak cipta menganut sistem konstitutif, yakni pendaftaran merupakan syarat utama untuk mendapatkan perlindungan. Jika sudah didaftarkan maka kerajinan kerawang Gayo Lues memiliki jaminan hukum yang kuat dan pasti sehingga dapat melindungi produknya dari persaingan curang atau pencaplokan dari pihak lain serta pembohongan publik. Selain itu dengan didaftarkan kerajinan kerawang gayo lues ini sebagai indikasi geografis bisa membangun nama produk ini semakin dikenal di pasar internasional. Kerajinan kerawang Gayo Lues sudah memenuhi unsur-unsur dalam persyaratan pengajuan pendaftaran sesuai dengan Undang-Undang Nomor 28 Tahun 2014 tentang Hak Cipta.

2. Hambatan dalam perlindungan kerajinan kerawang Gayo Lues karena kurangnya pemahaman dari pihak masyarakat atau pengrajin yang ada di Kabupaten Gayo Lues dan pihak pemerintah menganggap masalah pendaftaran kerawang Gayo Lues ini tidak terlalu penting sehing ga tidak ada lembaga khusus yang menangani tentang kerawang Gayo Lues. Kemudian kurang nya sosialisasi tentang HKI oleh pemerintah daerah kepada para pengrajin kerawang Gayo Lues dan masyarakat yang ada di Kabupaten Gayo Lues dan Lukup atau Aceh Timur.

3. Upaya yang dilakukan untuk mendapat pelindungan hukum terhadap kerajinan kerawang Gayo Lues ialah dengan mendaftarkan kerawang Gayo Lues ini kepada HKI agar mendapatkan sertifikat sebagai bukti bahawa kerawang Gayo Lues telah didaftarkan. Kemudian melakukan seminar sosialisasi kepada masyarakat akan pentingnya perlindungan hukum.

\section{B. Saran}

1. Mengenai indikasi geografis, sudah seharusnya masyarakat yang memiliki usaha kerajinan kerawang Gayo Lues mengerti tentang HKI.

2. Pemerintah daerah seharusnya membuat suatu lembaga khusus pembinaan di tiap-tiap kecamatan yang ada di Gayo Lues agar para pengrajin yang kurang pendidikannya dapat mengerti pentingnya perlindungan hukum.

${ }^{22}$ Asmaini, Guru Pengrajin di Dekranas Kerawang Gayo Lues Kecamatam Blangkejeren Kabupaten Gayo Lues, Narasumber, Wawancara, Tanggal 15 Januari 2020 
3. Seharusnya para pihak yang terkait baik itu dari pihak Dirjen HKI, pemerintah Gayo Lues, Majelis Adat Aceh Gayo Lues maupun Departemen Perindustrian, untuk lebih meningkatkan sosialisasi tentang UU Merek Dan Indikasi Geografis dan UU Hak Cipta.

\section{Daftar Pustaka}

Alif Rahana Putra, 2013, Skripsi, Perlindungan Hukum Terhadap Sarung Sutera Wajo, Fakultas Hukum, Universitas Hasanuddin Makasar.

Amiruddin Dan Zainal Asikin, 2004, Pengantar Metode Penelitian Hukum,Pt.Raja $\quad$ Grafindo Persada, Jakarta.

Anonym, 2007, Haki Dan Implementasinya Terhadap Litbang, Investasi Dan Inovasi Di Indonesia, Departemen Perindustrian, Jakarta.

Ansar Salihin Dkk, 2019, Motif Ukiran Kerawang Gayo Pada Rumah Adat Gayo Di $\quad$ Kabupaten Aceh Tengah Provinsi Aceh, Jurnal Seni Rupa, Volume 08 Nomor 01.

Asian Law Group, 2002, Hak Kekayaan Intelektual (Suatu Pengatar), Alumni, Bandung.

Budi Agus Riswandi Dan M. Syamsudin, 2004, Hak Kekayaan Intelektual Dan Budaya Hukum, Pt.Raja Grafindo Persada, Jakarta.

Devi Rahayu, Februari 2011, Perlindungan Hukum Terhadap Hak Cipta Motif Batik $\quad$ Tanjungbumi Madura, Volume 23 Nomor 1, Jurnal Ilmiah Mimbar Hukum.

Eddy Damian, 2005, Hukum Hak Cipta Edisi Kedua Cetakan Ke-3,Pt. Alumni, Bandung.

I Gusti Ayu Agung Ratih Maha Iswari Dwija Putri, 2020, Permasalahan Dalam Implementasi Ketentuan Trips Agreement Berdasarkan Undang-Undang Nomor 13 Tahun 2016 Tentang Paten, Jurnal Hukum, Vol.8 Nomor 7.

Irfa'ina Rohana Dkk, 2016, Ukiran Kerawang Aceh Gayo Sebagai Inspirasi Penciptaan Motif $\quad$ Batik Khas Aceh Gayo, Karya Ilmiah, Tanggal Disetujui Naskah 22 Desember 2016.

Juliawati Ningsih Dkk, 2018, Perbedaan Motif Kerawang Gyo Lues Dan Aceh Tengah, Jurnal Ilmiah, Volume Lii, November, Nomor 4;356-357, Mahasiswa Program Studi Pendidikan Seni Drama Tari Dan Musik, Universitas Syiah Kuala,

Ketut Pernama Sari Dan Ida Bagus Putra Atmaja, 2019, Perlindungan Hukum Motif $\quad$ Tradisional Kerajinan Perak Celuk Sebagai Warisan Budaya, Jurnal Ilmiah, Program Kekhususan Hukum Bisnis Fakultas Hukum, Universitas Udayana, Volume 7 Nomor 9.

Miranda Rising Ayu, 2006, Memperbincangkan Hak Kekayaan Intelektual Indikasi Geografis,Pt.Alumni, Bandung.

Ni Nyoman Ayu Pasek Satya Sanjiwani Dan Suatra Putrawan, Pengaturan Perlindungan Hukum Terhadap Hasil Karya Cipta Seni Ukir Patung Kayu Sebagai Ekspresi Budaya Tradisional 
Berdasarkan Undang-Undang Nomor 28

Tahun 2014 Tentang Hak Cipta, Program Kekhususan Hukum Bisnis, Fakultas Hukum, Jurnal Ilmiah, Universitas Padjaran.

Ni Ketut Sari Adnyani, 2016, Perlindungan Hukum Indonesia Geografis Terhadap Kerajinan

Tradisional Tenun Gringsing Khas Tenganan, Jurnal, Universitas Pendidikan Ganesha, Seminar Nasional Pengabdian Masyarakat,

Ok Saidin, 2007, Aspek Hukum Kekayaan Intelektual (Intellectual Property Rights), Pt.Raja Grafindo Persada, Jakarta.

Sudjana Dkk, 2018, Implikasi Perlindungan Indikasi Geografis Berdasarkan Undang- Undang Nomor 20 Tahun 2016 Terhadap Pengembangan Ekonomi Sosial, Jurnal Ilmu Hukum Kenoktarian, Jurnal Hukum, Universitas Padjadjaran.

Winda Risna Yessiningrum, Perlindungan Hukum Indikasi Geografis Sebagai Bagian Dari Hak Kekayaan Intelektual, Skripsi, Mahasiswa Megister, Fakultas Ilmu Hukum, Universitas Mataram.

Yulia, 2016, Modul Hak Kekayaan Intelektual, Unimal Press, Universitas Malikussaleh. 